\title{
THE MIGRATION CRISIS IN THE CASE \\ LAW OF THE ECHR - SOME REMARKS ON \\ THE OBLIGATIONS OF COUNTRIES TO REFUGEES AND IMMIGRANTS
}

\begin{abstract}
This paper focuses on the scope of obligations of states towards refugees and migrants under the ECHR. It's introductory part that describes the significance of the ECHR for the European legal order is followed by a detailed analysis of the state's obligations broken down according to ratione personae - ratione loci - ratione materie scheme. The paper clarifies the distinction between "migrants" and "refugees" (1951 Geneva Convention) and defines situations when ECHR can be applied outside the territory of the State Party (especially in the context of border control and maritime operations). The final part of the paper concentrates of the set of minimal substantial guaranties towards migrants and refugees in the context of living conditions in the centers for foreigners, right to liberty and security of person and right to respect for family life.
\end{abstract}

Keywords: refugees, migrants, migration crisis, European Union, European Convention on Human Rights, extraterritorial jurisdiction, non-refoulement, detention of foreigners, prohibition of ill-treatment, family life

* Department of International and European Law, Cardinal Stefan Wyszyński University (UKSW) The article expresses the personal opinions of the author only. 


\section{Introduction: the European Union and the European Convention on Human Rights}

According to Article 7, paragraph 3 of the Treaty on the European Union (TEU), basic rights, guaranteed by the Convention for the Protection of Human Rights and Fundamental Freedoms ("ECHR" or "Convention") as well as those arising from the constitutional traditions of member states, constitute a part of EU law as general rules of law. According to Article 7, paragraph 1 of the TEU, the European Union recognises laws, freedoms and rules defined in the Charter of Fundamental Rights of the European Union ("CFR" or "Charter"), which have the same legal force as Treaties. Article 52 (3) of the Charter constitutes that in the scope that it contains laws which correspond to laws guaranteed in the Convention, their meaning and scope are the same as laws established by the Convention (which is not an obstacle for EU law had wider protection). The above provisions ensure the limitation of the consequences of institutional dualism of the European Union and Council of Europe and ensure the necessary internal coherence of the European system of protecting human rights, which is a part of both the Convention and the Charter ${ }^{1}$. However, in order to specify the legal framework of the EU's answer to the migration crisis it is essential to reconstruct the current Strasbourg standard. This requires an accurate interpretation of EU law understood as a process of establishing the actual meaning of EU legal norms, explaining their content, indicating their scope and defining everything that allows them to have an influence ${ }^{2}$. It should be highlighted that the meaning and scope of rights guaranteed in the ECHR are defined in practice not so much in the text or its footnotes, which naturally should be general in character, but above all through the case law of the European Court of Human Rights ("ECtHR" or "Strasbourg"). This case law is taken into consideration

1 See: F. Jasiński, Karta praw podstawowych: struktura, zakres regulacyjny $i$ dotychczasowe znaczenie $w$ praktyce [Charter of Fundamental Rights: structure, scope of regulation, current meaning in practice] [in:] J. Barcz, 'Ochrona Praw podstawowych w Unii Europejskiej' [Protection of fundamental rights in the European Union], C. H. Beck, Warsaw 2008, p. 48.

2 C. Mik, Europejskie prawo wspólnotowe. Zagadnienia teorii i praktyki [European community law. Issues of theory and practice], C. H. Beck, Warsaw 2000, p. 683-684.

3 See: Explanation to Article 52 of the Charter. As results from Article 6, paragraph 1 TEU, the laws, freedoms and rules included in the Charter are interpreted according 
in the operational interpretation of the Charter undertaken by all EU institutions, not excluding the Court of Justice of the European Union ("CJEU" or "Luxemburg") 4 . It should be noted that the Convention is a "live instrument" which is continuously conformed to the needs and challenges of modern life by ECtHR ${ }^{5}$. Strasbourg case law is also one of the elements that make concrete the substance of fundamental laws as general rules of EU law ${ }^{6}$. It should also be highlighted that the given external systemic interpretation is not the only and adequate method of decoding which has application in legal norms. For an exhaustive analysis, the following methods of the interpretation of the Charter have to be taken into account: (i) pro homine (interpreting in the interest of the entitled party); (ii) legalistic (in accordance with the rules of democracy and rule of law); (iii) flexible (taking into consideration the diversity and distinctness existing in the member states); (iv) evolutionary (taking into account social changes and scientific and technological progress); (v) responsible (interpreting laws in accordance with their message, not separating them from obligations) ${ }^{7}$. It is important to note that when searching for material sources of fundamental laws, CJEU does not limit itself to the ECHR ${ }^{8}$. Nevertheless, a reconstruction of the binding EU standard is not possible without getting to know the standpoint expressed by the ECHR for refugee and migrant cases. Strasbourg case law serves the CJEU above all to make concrete the content of fundamental laws which are tools that define

to the general provisions agreed in title VII of the Charter regulating its interpretation and use as well as suitable consideration of the explanations, mentioned in the Charter, which define the source of these provisions. See also: table of equivalence in: M. Jarmoszka, Reguły wykładni Karty praw podstawowych Unii Europejskiej [Rules of interpretation of the Charter of Fundamental Rights], [in:] ed. C. Mik. K. Gałka, 'Prawa podstawowe w prawie i praktyce Unii Europejskiej' [Fundamental rights in law and practice], TNOiK, Toruń 2009, pp. 102-105.

4 The first ruling in which CJEU quoted ECHR case law was the verdict of 13.03.1994 concerning the Familiapress case, C-368/95, para. 26.

5 M.A. Nowicki, Wokół Konwencji Europejskiej. Komentarz do Europejskiej Konwencji Praw Człowieka [Around the European Convention. A Commentary to the European Convention on Human Rights], Wolters Kluwer, SIP Lex 2017, para. 16.4.

6 See: verdict of the Court of First Instance of 20.02.2001 in the MannesmannröhrenWerke AG case, T-112/98, para. 60.

7 C. Mik, Karta praw podstawowych Unii Europejskiej. Zagadnienia podstawowe [Charter of Fundamental Rights. Basic Issues] [in:] A. Podraza (ed.), 'Traktat Nicejski' [The Treaty of Nice], TN KUL, Lublin 2001, p. 91-92.

8 Omega, C-36/02, Judgment of 14.10.2004, para. 33. 
the scope of protection entitled to the individual on the basis of EU law or define the scope of any permissible restrictions ${ }^{9}$.

This article does not purport to provide an all-embracing study of the topic under discussion. It focuses on several key issues from the point of view of the current migration crisis. The article focuses above all on the mass influx of both refugees and migrants via the Mediterranean Sea chiefly in dangerous conditions, which make it difficult determine their identities and which of these people are 'refugees' (determined by international law). The scale of the phenomenon generates reception problems, primarily in the context of living conditions prevailing in the centres where refugees and migrants reside, as well as the rules and ways in which they are placed there. In turn, the difficulty in establishing the identity of these refugees and migrants as well as public concerns about the inflow of significant numbers of foreigners has again raised questions about the range of duties of the EU and states in the context of possible expulsions of refugees. The question of the possibility of bringing together families of refugees and not separating them (again in the context of expulsion) remains open. The way that refugees and migrants reach the borders of the $\mathrm{EU}$ (by sea) raises the question of the range of responsibilities of the EU and the states implementing a common migration policy regarding those refugees and migrants who have not crossed any state border but were taken in international waters. This article discusses these issues by analysing them from the point of view of Strasbourg case law.

\section{Ratione personae Obligations: the terms "refugee" and "migrant"}

Commonly speaking, the term "refugee" includes all persons forced by circumstances beyond their control, such as armed conflicts, persecution

9 C. Mik, Znaczenie postanowień EKPCz dla ochrony praw podstawowych jako ogólnych zasad prawa UE [The meaning of ECHR for protection of fundamental rights as general principles of EU law], [in:] red. J. Barcz, 'Ochrona praw podstawowych w Unii Europejskiej' [Protection of fundamental rights in the European Union], C.H. Beck, Warszawa 2008, p. 220. 
or natural disasters to leave their place of residence ${ }^{10}$. However, in the legal sense, a refugee is a person who, cumulatively: (1) is persecuted because of his/her race, religion, nationality, belonging to a particular social group or because of his/her political beliefs or has a legitimate fear of such persecution; (2) he/she lives outside their country of citizenship; (3) cannot benefit from the protection of that country ${ }^{11}$. In turn, a "migrant" is someone who leaves their place of residence not for fear of persecution but for the purpose of raising their quality of life ${ }^{12}$. This distinction is key from the point of view of international refugee law and migration management. Analyzing the matter from the point of view of international human rights law, it should be noted that none of the provisions of the Convention refer only to "refugees". On the contrary, the Convention protects the rights of every human being ${ }^{13}$. In this sense, the scope of obligations of ratione personae arising from the Convention is narrower than those arising from the Charter, which contains a provision aimed at people seeking international protection. Article 18 of the CFR [Right to asylum] provides that:

10 G.S. Goodwin-Gill, J. McAdam, The Refugee in International Law, Oxford University Press, Oxford 2007, p. 15.

11 Article $1 \mathrm{~A}$ of the Convention relating to the Status of Refugees, signed at Geneva on 28.07.1951 (hereinafter: "Geneva Convention"). This convention shall cease to apply [Article $1 \mathrm{C}$ ] to any person falling under the terms of section A if: (1) He has voluntarily re-availed himself of the protection of the country of his nationality; or (2) Having lost his nationality, he has voluntarily re-acquired it; or (3) He has acquired a new nationality, and enjoys the protection of the country of his new nationality; or (4) He has voluntarily re-established himself in the country which he left or outside which he remained owing to fear of persecution; or (5) He can no longer, because the circumstances in connexion with which he has been recognized as a refugee have ceased to exist, continue to refuse to avail himself of the protection of the country of his nationality.

Furthermore, in Article I F, the provisions of the Convention shall not apply to any person with respect to whom there are serious reasons for considering that: (a) he has committed a crime against peace, a war crime, or a crime against humanity, as defined in the international instruments drawn up to make provision in respect of such crimes; (b) he has committed a serious non-political crime outside the country of refuge prior to his admission to that country as a refugee; (c) he has been guilty of acts contrary to the purposes and principles of the United Nations.

12 Office of the UN High Commissioner for Refugees, https://emergency.unhcr.org/ entry/44938/migrant-definition (accessed 6.12.2017).

13 Subject to a separate provision prohibiting the collective expulsion of "foreigners" (Article 4 of the Fourth Additional Protocol to the ECHR). 
The right to asylum shall be guaranteed with due respect for the rules of the Geneva Convention of 28 July 1951 and the Protocol of 31 January 1967 relating to the status of refugees and in accordance with the Treaty on European Union and the Treaty on the Functioning of the European Union.

Nevertheless, the Strasbourg Court includes in its case law the fact that a person is a refugee or is applying for such status. He points out that when they take action to prevent illegal immigration, they must abide by their obligations under the Geneva Convention. The legitimate interest of the state in preventing increasingly more frequent attempts to illegally breach migration restrictions cannot lead to the deprivation of asylumseekers from protection under international law ${ }^{14}$. This general principle is translated into case law practice, because the Strasbourg Court requires the treatment of refugees in a way that takes into account their particular situation ${ }^{15}$ no less favourably than conventional migrants ${ }^{16}$.

The Court also takes into account the extraordinary nature of the current crisis. It indicates that the "states bordering the European Union are now facing serious difficulties in attempting to cope with the growing influx of migrants and asylum seekers" and that it "does not underestimate the burden and pressure that this situation has on the larger states in the current economic crisis" and that "it is particularly aware of the difficulties associated with migration by sea, which has made border control in southern Europe more complicated" ${ }^{\text {"17 }}$. Strasbourg case law also demonstrates that the:

Court is aware of the great migratory crisis that began in 2011. The arrival of a mass of migrants from North Africa has undoubtedly created organisational, logistical and structural difficulties for authorities. Due to the many political, economic and social factors that caused the migration crisis and taking into account the difficulties faced by the Italian authorities, the Court found that the situation in 2011 was exceptional. The authorities would have be overburdened if they had had an obligation to analyse these factors 69.

16 Hode and Abdi v. United Kingdom, No. 22341/09, Judgment of the ECHR of 6.11.2012, paras. 53-54.

17 Hirsi Jamaa and Others v. Italy, No. 27764/09, Judgment of the ECHR of 23.02.2012, para. 122; MSS v. Belgium and Greece, No. 30696/09, Judgment of 21.01.2011 para. 223. 
in detail and predict the scale and timing of the influx of migrants. The difficulties inherent in such a crisis cannot be invoked per se in order to justify breaching Article 3 . However, it would have been be artificial to examine the facts of the case without considering its general context ${ }^{18}$.

\section{Ratione loci Obligations}

\subsection{Intra and extra-territorial obligations}

The specific nature of states' response to the migration crisis was and is endeavouring to exclude the responsibility of states for persons who can apply for refugee status by closing access to the EU. To this end, refugees are intercepted outside the EU (including on the high seas) or placed in reception centres outside the $\mathrm{EU}$, where possible applications for granting refugee status can be received ${ }^{19}$. It should be examined whether this practice may exclude applying rules of the Convention and Charter to incidents occurring outside the EU.

According to Article 1 of the ECHR, the parties ensure every human "under its jurisdiction" the rights and freedoms it defines. This is a reflection of the clear principle according to which the state is not responsible for every occurrence committed anywhere, at anytime and by anyone, but only for acts that can be attributed to it under international law ${ }^{20}$.

18 Khlaifia et al. v. Italy, No. 16483/12, Judgment of the Grand Chamber of the ECHR of 15.12.2016, paras. 137, 179-180, 185. The Tribunal draws practical consequences from these declarations. In particular, in the Khlaifia case, having found that migrants were forcibly detained in overcrowded reception centre where hygiene was poor and there was no contact with the outside world (para. 188), it stated that "taking into consideration all the then existing factors and in light of the particular circumstances of the case", the treatment of the complainants did not exceed the level of complaint required to be able to speak of a violation of the Convention (para. 199).

19 C. Costello, The Human Rights of Migrants in European Law, Oxford University Press, Oxford 2016, pp. 231-232.

20 See Article $2 \mathrm{~A}$ of the Articles on the Responsibility of States for Internationally Wrongful Acts by the International Law Commission (text attached to UN General Assembly Resolution 56/83 of 12.12.2001, revised by document No. A/56/49 (Vol. I)/ Corr. 4, M. Balcerzak, Odpowiedzialność państwa-strony Europejskiej konwencji o ochronie praw człowieka i podstawowych wolności. Studium prawnomiędzynarodowe [Responsibility 
The issue of the extraterritorial application of treaties in the field of human rights is considered extremely controversial ${ }^{21}$. Nevertheless, it is possible to reconstruct the benchmark according to which the state is responsible for events that occurred within its jurisdiction, and hence (a) on its territory, even if it did not effectively control it ${ }^{22}$; to the detriment of all persons (b) under its authority or effective control, because the state exercises effective control over the area (executes executive or judiciary authority or public authority usually performed by a sovereign government ${ }^{23}$ or because it has effective control over the perpetrator of the violation ${ }^{24}$.

of a state party to the European Convention on Human Rights and Fundamental Freedoms. An international law study], TNOiK, Toruń 2013, p. 289).

${ }^{21}$ Due to the legally complex nature and political excitement associated with such matters in the Strasbourg system and despite extensive ECHR case law in this field, complaints are immediately forwarded to the Grand Chamber of the Court. See e.g. Hassan v. United Kingdom, No. 29750/09 and Jaloud v. the Netherlands, No. 47708/08.

22 Some countries, by ratifying international agreements, reserve the right that they are not responsible for incidents occurring in those territories in which they do not exercise effective control (e.g. Moldova's stipulation on the ratification of the ECHR:

The Republic of Moldova declares that it will be unable to guarantee compliance with the provisions of the Convention in respect of omissions and acts committed by the organs of the self-proclaimed Trans-Dniester republic within the territory actually controlled by such organs, until the conflict in the region is finally settled (...)

These declarations are contrary to the purpose and subject of treaties in the field of the protection of human rights, which are by nature protective in nature.

${ }^{23}$ Al-Skeini v. The United Kingdom, No. 47708/08, Judgment of the Grand Chamber of the ECHR of 7.07.2011, para. 138.

24 An example of this is the sinking of the Greenpeace ship 'Rainbow Warrior' by French intelligence officers in New Zealand, when there was practically no doubt that France as a state was responsible for their actions. See the first arbitration judgment in the Rainbow Warrior case of 6.07.1986 No. 74, p. 241; M. Pugh, Legal Aspects of the Rainbow Warner Affair, 'The International and Comparative Law Quarterly' 1987, vol. 36, No. 3, pp. 655-669. The judgments of the Grand Chamber of the ECHR of 12.05.2005 in Ocalan v. Turkey, No. 46221/99, para. 91 and of 16.11.2004 in Issa v. Turkey, No. 31821/96, para. 71: "A state may also be liable for violations of rights and freedoms under the Convention against persons who are on the territory of another state but who are under the former's authority and control through its officers operating there, whether legally or illegally." The State's responsibility in such cases is derived from the fact that Article 1 of the Convention cannot be interpreted as permitting a state party to commit a violation of the Convention, which it could not commit on its own territory, or on the territory of another country. The ECHR stated that Öcalan was under the jurisdiction of Turkey at the time when he was handed over to Turkish officials in Nairobi, Kenya, where obviously Turkey had not territorial jurisdiction in the slightest. The position should be considered established (Al-Skeini and 
The CFR does not contain the equivalent of Article 1 of the ECHR. CFR Article 51 (1), however, provides that it applies to the institutions and bodies of the EU and to Member States "in so far as they apply EU law". An interpretation supported by a detailed analysis of subject matter and the purpose of the Charter which is to increase the protection of human rights shows that what is decisive for the territorial scope of the Charter (and EU law in general) are subjective and physical issues, that is whether a given action or breach can be attributed to the EU or its states (subjective test), and whether it occurred in the implementation of EU law (physical test $)^{25}$. This is an interpretation of practical consequences consistent with the ECHR's current position regarding the interpretation of the concept of "keeping under jurisdiction". This is also confirmed in the position of the CJEU, which indicates that EU law may apply not only within its borders (of course), but also beyond them.

\subsection{Territorial Jurisdiction}

At the current stage of development of international law, it is beyond question that a person is "under the jurisdiction of the state" ${ }^{26}$ is someone who is physically present within its territory ${ }^{27}$, i.e. within

Others v. the United Kingdom, No. 55721/07, Judgment of the Grand Chamber of the ECHR of 7.07.2011, paras. 136-137). A good analysis of Strasbourg case law in the territorial scope of the ECHR can be found in: M. Milanović, Al-Skeini and Al-Jedda in Strasbourg, 'European Journal of International Law' 2012, vol. 23, no. 1, pp. 121-139.

${ }^{25}$ Edit. S. Peers et al., The EU Charter of Fundamental Rights: A Commentary, CH BeckHart-Nomos, Oxford 2014, p. 1662.

26 Without going into detail, which is beyond the scope of this work, looking at the differences between this and similar concepts such as "suitability" and "competence", it is enough to paraphrase K.C. Randall and M. Shaw that this concerns a state's justified exercising of its competence to determine the legal situation, the ability to influence people, places, and events (see T. Ostropolski, Zasada jurysdykcji uniwersalnej w prawie międzynarodowym [The Principle of general jurisdiction in international law], Instytut Wydawniczy Euro Prawo, Warsaw 2008, pp. 18-20).

27 The territory of a state is three-dimensional space, over which the state has sovereignty. The territory includes: land, coastal waters, the ground below the land and waters, and the air space over land and sea (W. Góralczyk, S. Sawicki, Prawo międzynarodowe publiczne [Public International Law], Wolters Kluwer, Warsaw 2015, p. 168-169. 
its borders ${ }^{28}$. Polish law indicates that the Republic of Poland exercises its sovereignty over its territory and the earth beneath it, its internal and territorial waters, their bottoms and the earth beneath them, as well as its air space above its territory, its internal and territorial waters ${ }^{29}$. Therefore, whoever resides in this area so defined (even if illegally), remains under the authority of the Republic of Poland (i.e. under its jurisdiction). This is of practical significance for people who have crossed state borders outside of the officially designated crossings, through an official crossing but illegally (by using false documents) who legally crossed the border but have lost the right to reside within the territory of the Republic of Poland but crossed the border and have not yet gone through border control (e.g. remain in the transit zone of the airport ${ }^{30}$ ). Entry into Polish jurisdiction takes place by physically crossing the Polish state border and not with the granting of permission to enter. From this (territorial) perspective, someone will not be under Polish jurisdiction if they are allowed to enter if the shared border control takes place on the territory of an adjoining state $^{31}$, however, they will be under Polish jurisdiction if this person is

28 Polish law defines a border consistent with international law as a vertical surface crossing the boundary line, separating the territory of the Polish state from territories of other countries and from the high seas. The state border also demarcates airspace, waters and the interior of the Earth (Article 1, Article 6 of the Act of 12.10.1990 on the Protection of the State Border (Polish OJ 2018, item 1869, as amended).

${ }^{29}$ See Article 6 of the Act of 12.10.1990 on the Protection of the State Border and Article 2 para. 2 and Article 4 and 5 of the Act of 21 March 1991 on Maritime Areas of the Republic of Poland and Maritime Administration (Polish OJ of 2013, item 934, as amended). Due to the principle of estoppel, Poland in international relations cannot determine the meaning of being under jurisdiction in a different, more favourable way in a given legal system.

${ }^{30}$ Z.A. and Others v. Russia, No. 61411/15, Judgment of the ECHR of 28 .03.2017, para. 87.

31 In practice, there are situations where two neighbouring countries perform border duties within one facility, entirely on the territory of one of the countries making it possible to resign from maintaining two separate border infrastructures on both sides of the border (joint border control). Poland has an agreement on joint control of the border with Ukraine (Agreement between the Government of the Polish Republic and the Cabinet of Ministers of Ukraine on cooperation in carrying out checks on persons, goods and vehicles crossing the Polish-Ukrainian state border, signed in Kiev on 25 June 2001. Polish OJ 2003, No. 196, item 1916). 
not yet been authorised to enter but the border control is on the territory of Poland ${ }^{32}$.

From this follows the sceptical stance of the ECHR regarding the arguments of states not applying the Convention to the actual or alleged refugees facing border control on their territory only because the border control procedure has not yet been carried out ${ }^{33}$. This authority expresses the view that it is that this person is prohibited from not only expulsion but even being forced return to a country where their life or freedom could be endangered (non-refoulement). From this stems the obligation to accept foreigners at the border into to consider their application for granting refugee status ${ }^{34}$.

\subsection{Extracurricular jurisdiction}

Taking into consideration the above case law, states seek to shift border control outside their territory so that refugees and migrants are not in their

32 Jurisdiction is also understood in this way in the practical aspect of Polish law enforcement and the judicial authorities. It follows from established court and prosecutor practice that crimes committed during border control in Poland (e.g. during border control at the Terespol crossing) are prosecuted on the basis of territoriality (Article 5 of the Polish Penal Code "applies to the perpetrator who committed a prohibited act on the territory of the Republic of Poland, as well as on a Polish ship or plane, unless an international agreement to which the Republic of Poland is party states otherwise") and crimes committed during joint border control on the side of a neighbouring state (e.g. border at Zosin) under the rules specified in chapter XIII of the Penal Code "Responsibility for crimes committed abroad".

33 See provisional measures (interim measures) in cases of $M K v$. Poland, No. 40503/17, MK et al. v. Poland, No. 43643/17, MA et al. v. Poland, No. 42902/17.

34 A. Florczak, Ochrona uchoźców w świetle prawa wspólnotowego [Protection of refugees in light of community law] [in:] A. Florczak (ed.), 'Ochrona praw podstawowych w Unii Europejskiej. Wybrane zagadnienia' [Protection of fundamental rights in the European Union], Łoś Graf, Warsaw 2009, pp. 200-201. See also Hirsi Jamaa et al. v. Italy, No. 27764/09, Judgment of the Grand Chamber of the ECHR of 23.02.2012, paras. 169-180. However, the doctrine expressed the view that Article 3 shall not apply in the event of refusal of entry, because the person affected by it is not yet under the authority of a member state of the Convention. Nor does it apply to the refusal to grant asylum, unless accompanied by a decision to remove that person from the territory of the State. (L. Garlicki, Konwencja o ochronie praw człowieka i podstawowych wolności. Tom I. Komentarz do artykutów 1-18 [Convention for the Protection of Human Rights and Fundamental Freedoms. vol. 1, A commentary to Arts. 1-18], CH Beck, Warsaw 2010, p. 131). 
territorial jurisdiction. However, according to Strasbourg case law, they also exercise their jurisdiction according to Article 1 of the Convention (applying EU law according to Article 51 of the Charter).

In the context of the migration crisis, the most common case of extracurricular jurisdiction are activities that take place on board a vessel flying the flag of a given country. Most refugees and migrants try to get to the EU by sea, many in vessels not seaworthy, which can be a direct cause of shipwreck. These ships are often intercepted and the migrants and refugees taken on board by European coastguard vessels, or rescued as part of rescue operations if on the high seas ${ }^{35}$. Although the European ship on which the migrants and refugees are taken is not a floating part of the territory of that particular state ${ }^{36}$, according to the customary international law codified in the Convention on the Law of the Sea, while on the high seas it remains solely under that state's exclusive jurisdiction ${ }^{37}$. This principle is confirmed in Polish legislation ${ }^{38}$. Therefore, the estoppel principle must also refer to refugees and migrants who find themselves on Polish ships: these refugees and migrants remain "under the jurisdiction" of Poland ${ }^{39}$.

Sometimes officers or soldiers of a Member State board a vessel flying under a foreign flag. The moment they take control of the vessel, that state's obligations towards the people on the ship come into force. For

35 Pursuant to Article 96 (1) A of the Convention on the Law of the Sea [obligation to provide assistance], each country obliges the captain of the ship flying its flag, as long as the captain can do so without seriously endangering the ship, crew or passengers to help every person at sea in danger.

36 The Polish Supreme Court in 1964 rejected the "theory of territoriality of ships" (resolution of 20.02.1964, VI KO 6/63, OSNKW 1964 No. 6, item 96).

37 Article 92, Paragraph 1 of the UN Convention on the Law of the Sea stipulates that vessels sail under the flag of one State only and, except as expressly provided for in international treaties or in the Convention, are under that exclusive jurisdiction on the high seas. In addition, Articles 95 and 96 of the Convention [Immunity of warships on the high seas] and [Immunity of ships used only on government non-commercial service] provide that on the high seas war ships and vessels used exclusively for government non-commercial services have complete immunity from the jurisdiction of any country other than the flag State.

38 The Republic of Poland is considered to be competent to regulate public law relations related to ships of Polish affiliation and all incidents taking place on board (Article 6 of the Maritime Code, Article 5 of the Penal Code).

39 Hirsi Jamaa et al. v. Italy, No. 27764/09, Judgment of the Grand Chamber of the ECHR of 23.02.2012, paras. 81-82. 
the purpose of the Convention, these persons enter into its jurisdiction at that moment ${ }^{40}$.

\section{Ratione materiae Obligations}

\subsection{Non-refoulement}

According to Article 2 paragraph 1 ECHR 1 , every person's right to life is protected by law, therefore nobody can be deliberately deprived of life ${ }^{41}$. According to Article 3 no one should be subjected to torture or inhuman or degrading treatment or punishment. ECHR case law assumes that torture is inhuman and degrading treatment of the highest order (acute physical or mental suffering $)^{42}$. The difference between torture and inhuman and degrading treatment is quantitative. The latter is of a lesser order, but it must be borne in mind that since the Convention is a "living instrument", events currently classified as "only" inhuman and degrading treatment may be classified as torture in the future ${ }^{43}$. According to established ECHR case law, states have the right to control the entry and stay of foreigners on their territory. They also have the right to expel them ${ }^{44}$ especially since,

40 Medvedyevi v. France, No. 3394/03, Judgment of the ECHR of 29.03.2010, paras. 65-67.

41 Pursuant to paragraph 2 of the said provision, depriving someone of life shall not be regarded as contrary to this article if it occurs as a result of the use of force which is absolutely necessary: (a) in the defence of any person against unlawful violence, (b) for the purpose of enforcing lawful arrest or preventing a person deprived of liberty according to law, (c) in actions lawfully taken to suppress riots or insurrections. ECHR case law (Al-Saadoon and Mufdhi v. The United Kingdom, No. 61498/08, Judgment of 2.03.2010, para. 120) considered it contrary to the Convention depriving someone of life in the execution of a court judgment, conviction of a crime for which the law provides punishment (Article 1 (1) in fine the Convention).

42 Ireland v. The United Kingdom, No. 3510/71, Judgment of 18.01.1978, paras. 167-168.

43 Selmouni v. France, No. 25803/94, Judgment of 28.07.1999, para. 101.

44 Pursuant to Article 4 of the Fourth Additional Protocol to the ECtHR, this expulsion cannot be "collective", which means that every expellee must have a real and effective opportunity to raise arguments against expulsion, and the decision regarding each expellee should be taken individually, after proper examination. In the context of the migration crisis, due to the scale of migration, many decisions are taken in similar cases and to recognise that the expulsion was individual, is does not need to be preceded by an individual interview. It is enough if the identity of each of the deportees has 
as indicated above, the Convention does not contain the right to asylum. Nevertheless, the expulsion, extradition or the obligations of an alien to return may result in the violation of Article 2 or 3 there is a "genuine risk" that they may succumb to treatment that is contrary to these regulations ${ }^{45}$.

The burden of proof in this respect lies with the complainant, but the ECHR also collects information ex officio ${ }^{46}$. It is based in particular on reports of reliable non-governmental organizations (Amnesty International, Human Rights Watch), international bodies and national services (e.g. US State Department reports) ${ }^{47}$. In order to reconstruct the scope

been confirmed, and the foreigner, who can reasonably be expected to be expelled, had a real opportunity to draw the attention of the authorities to the circumstances against the expulsion. This real possibility may only arise from the period under the jurisdiction of the State Party (Khlaifia and Others v. Italy, No. 16483/12, Judgment of the Grand Chamber of the ECHR of 15.12.2016, paras. 248-249). In Strasbourg case law, "expulsion" in the meaning of the said provision also means the return (refusal of permission to cross the border of persons under the jurisdiction of a State Party outside its territory to a third country. See Hirsi Jamaa et al. v. Italy, No. 27764/09, Judgment of the Grand Chamber of the ECHR of 23.02.2012, para. 177).

45 Hirsi Jamaa and Others v. Italy, No. 27764/09, Judgment of the Grand Chamber of the ECHR of 23.02.2012, paras. 113-114. The principle of non-refoulement results from Article 33 of the Geneva Convention:

No Contracting State shall expel or return ('refouler') a refugee in any manner whatsoever to the frontiers of territories where his life or freedom would be threatened on account of his race, religion, nationality, membership of a particular social group or political opinion. 2 . The benefit of the present provision may not, however, be claimed by a refugee whom there are reasonable grounds for regarding as a danger to the security of the country in which he is, or who, having been convicted by a final judgment of a particularly serious crime, constitutes a danger to the community of that country.

The Convention and the Charter do not know the equivalent of point 2 of this provision and therefore there is no realistic expectation that the Tribunal in Strasbourg (or Luxembourg) would accept the return or expulsion of a foreigner even if it posed a threat to the security of the state or society. Admittedly, in Article 17 of the Convention [Prohibition of abuse of rights] shows that none of the provisions of the Convention can be interpreted as granting any person the right to act or make an act to nullify the rights and freedoms listed in the Convention or to limit them to a greater extent than the Convention provides, but the provision never allowed the exclusion of the application of Article 2 and 3 even in relation to the perpetrators of the most serious crimes (Gäfgen v. Germany, No. 22978/05, Judgment of the Grand Chamber of the ECHR of 1.06.2010, Judgment of the ECHR of 7.07.1989, Soering v. the United Kingdom, No. 14038/88, para. 11).

46 Ed. D. Harris, M. O’Boyle, Harris, O'Boyle \& Warbrick: Law of the European Convention on Human Rights, Oxford University Press, Oxford 2014, p. 248.

47 L. Garlicki, op.cit., CH Beck, Warsaw 2010, p. 132. 
of obligations of states, it is essential that in the opinion of the ECHR the fact that a given armed conflict persists in a given country does not constitute a "real risk" of violating the applicant's rights there ${ }^{48}$, unless there is a particularly drastic case of widespread violence ${ }^{49}$, or the applicant does not belong to a group which is subject to systematic persecution ${ }^{50}$.

The protective function of the Convention means that Articles 2 and 3 are broadly interpreted. Firstly, according to Strasbourg, these articles prohibit extradition, delivery, removal, return (that is, "refoulement") and in general any transfer of a person (both citizen and foreigner) from one state to another, from one jurisdiction to another. Secondly, in the Convention, the principle of non-refoulement is absolute, independent of a given person and what they have done to be returned ${ }^{51}$. In practice, this means that the provisions of Articles 2 and 3 of the Convention also apply to particularly dangerous people, including those involved in terrorist activities. Thirdly, the state in which an expulsion is seen as incompatible with the Convention is understood not only as the country to which the person is to be expelled directly, but also any third country (even if it was not a party to the Convention). The actions of the expelling state are

48 Vilvarajah et al. v. the United Kingdom, No. 13163/87 et al., Judgment and the ECHR of 30.10.1991, para. 111; HLR v. France, No. 1/1996/630/813, Judgments of the ECHR of 22.04.1997, para. 44, Mamatukulov and Askarov v. Turkey, No. 46827/99 and 46951/99, Judgment of the ECHR of 4.02.2005, para. 73, NA v. the United Kingdom, No. 25904/07, Judgment of the ECHR of 17.07.2008, para. 114.

49 NA v. United Kingdom, No.25904/07, Judgment of the ECHR of 17.07.2008, para. 115.

50 Saadi v. Italy, No. 37201/06, Judgment of the Grand Chamber of the ECHR of 28.02.2008, para. 132.

51 Saadi v. Italy, No. 37201/06, Judgment of the Grand Chamber of the ECHR of 28.2.2008, para.138. To compare, it should be pointed out that the Geneva Convention does not recognise as a refugee a person who has serious grounds for believing that: (a) he has committed a crime against peace, war crimes or crimes against humanity in the meaning of international acts designed to establish provisions relating to these crimes; (b) has committed a serious crime of a non-political nature outside the country that adopted it, before being recognised as a refugee; (c) is guilty of acts contrary to the goals and principles of the United Nations. This convention allows for the expulsion of a refugee on which there are grounds for considering him as dangerous for the security of the country in which he resides, or who, being convicted by a final judgment for particularly serious crimes, poses a danger to the society of that state (Article 33 (2)). See also: K. Przybysławska, Niepożądani uchodźcy: granice ochrony i zasady wykluczenia w świetle prawa międzynarodowego [Unwanted refugees: boundaries of their protection and rules of preclusion in light of international law], UNHCR, Warsaw 2009. 
treated as the first link in a causal chain that led to subjecting a person to treatment contrary to Articles 2 and 3 which according to the ECtHR, allows it to attribute these violations to the state ${ }^{52}$.

\subsection{Living conditions in centres for foreigners}

The large-scale nature of migration has caused the forced deportation of refugees and migrants to special centres. ECHR case law requires them to have adequate living conditions there. Strasbourg is aware, however, that the migration crisis is an exceptional situation and creates serious difficulties due to the many different challenges that states have to overcome when refugees and migrants arrive (accommodation, rescue, care for those with special needs, providing social assistance to refugees and migrants as well as residents of areas in which they are staying, securing public order and safety, etc.). Therefore, the State may, without ill intent or blame, have difficulty ensuring that refugees and migrants who are forcibly detained in a reception centre have adequate conditions. The Strasbourg standard in this area was developed on the basis of the conditions of detention, but it is adequately applied in matters concerning conditions in such centres. Determining the actual state of affairs in these types of cases, the Court often refers to the positions and reports of non-governmental organizations ${ }^{53}$. Accommodation in a makeshift building, without the possibility of going outside and without access to clean towels, bedding and appropriate cleaning products is deemed a breach of Article $3^{54}$, no beds in the deportation centre (only dirty fold-out mattresses available), no space for taking a walk, sparse diets ${ }^{55}$. One should bear in mind the fact that degrading treatment is an absolute right and is not subject to restrictions and may not be suspended under any circumstances. Nevertheless, it would be artificial to study migration without considering the general context. The Tribunal is therefore inclined to conclude that there is no violation of Article 3 even if the living conditions in a given centre are far from

52 National Court Register $v$. The United Kingdom, No. 32733/08, ECHR decision of 2.12.2008, p. 17.

53 K.D. Magliveras, Migration Law in Greece, Wolters Kluwer, Alphen aan den Rijn 2011, p. 137.

54 S.D. v. Greece, No. 53541/07, Judgment of the ECHR of 11.06.2009, paras. 49-51.

55 Tabesh v. Greece, No. 8256/07, Judgment of the ECHR of 26.11.2009, paras. 15-17. 
ideal, if only these nuisances and ailments assessed in the general context of the crisis and the specificity of a particular case do not exceed a certain minimum level ${ }^{56}$.

\subsection{Right to liberty and security}

Pursuant to Article 5 (1) F of the ECHR every person has the right to liberty and security and no one can be deprived of their liberty except when lawfully arrested or detained, in order to prevent the entry of a person into the territory of a state or the deprivation of liberty of a person against whom extradition or extradition proceedings are pending. According to Article 5 (2) of the Convention, anyone deprived of liberty should be immediately informed in a language he understands about the reasons for this deprivation of liberty. Pursuant to Article 5 (4) of the Convention, anyone deprived of liberty has the right to appeal to court in order to immediately determine the legality of their deprivation of liberty and call for exemption if the deprivation of liberty is illegal.

Deprivation of liberty also includes the imprisonment of a refugee or migrant in a centre for foreigners if, according to the law, he cannot leave it voluntarily, even if such a centre was not furnished and structured like a prison ${ }^{57}$. The same applies to the placement of foreigners in certain border areas (transit zones), from which they cannot get into the country they have entered, and which they can leave only by returning to the country from which they came. The ECHR recognises this kind of placement not as a "restriction" but as a "deprivation" of freedom ${ }^{58}$. In view of this, it expects countries to precisely specify in national law when, on what terms and in how they will be deporting foreigners from such centres or zones $^{59}$. States are also obliged to indicate in a simple and unambiguous manner to the foreigner why they were deprived of liberty ${ }^{60}$. In practice,

56 Khlaifia et al. v. Italy, No. 16483/12, Judgment of the Grand Chamber of the ECHR of 15.12.2016, paras. 199 .

57 Abdolkhani and Karimnia v. Turkey, No. 30471/08, Judgment of the ECHR of 22.09.2009, para. 127.

58 Ilias and Ahmed v. Hungary, No. 47287/15, Judgment of the ECHR of 14.03.2017. On 18.09.2017, at the request of Hungary, the case was referred to the Grand Chamber.

59 Abdolkhani and Karimnia v. Turkey, No. 30471/08, Judgment of the ECHR of 22.09.2009, para. 135.

60 Ibid. 
it may not be clear whether the detention is actually carried out only in the context of migration i.e. to control the movement of people or secure the execution of a possible expulsion decision, or for the needs of criminal proceedings in connection with the circumstances in which the foreigner crossed the border (often illegally, sometimes using false documents). States must also ensure judicial control of decisions of the deprivation of liberty ${ }^{61}$.

\subsection{The right to respect for family life}

Pursuant to Article 8 of the ECHR everyone has the right to respect for their own private and family life. It is unacceptable to interfere with the exercise of this right, except in cases provided by statute and necessary in a democratic society due to state security, public safety or economic prosperity, protection of law and order and the prevention of crimes, protection of health and morals and the protection of rights and freedoms other people. These provisions should be taken into account when deciding on the admission of persons closest to already residing refugees and migrants (family reunification) and assessing the possibility of expelling a foreigner if expulsion negatively affects his private or family life (non-separation of families). It should also be taken into account that by deciding on the basis of Article 8 of the ECtHR, the Strasbourg Court pays special attention to the principle of protection of the child ${ }^{62}$, considering it a serious argument for joining (not separating) families, and

61 Ibid.

62 Tanda-Muzinga v. France, No. 2260/10, Judgment of the ECHR of 10.07.2014, para.76, Jeunesse v. The Netherlands, No. 12738/10, Judgment of the Grand Chamber of the ECHR of 3.10.2016, paras. 107-109; Sen v. the Netherlands, No. 31465/96, ECHR Judgment of 21.12.2001, para. 37; Tuquabo-Tekle and Others v. the Netherlands, No. 60665/00, ECHR Judgment of 1.12. 2005, para. 44. In this context, the provisions of Articles 3 and 10 of the UN Convention on the Rights of the Child are sometimes referred to. (Article 3 (1). In all actions concerning children, whether undertaken by public or private social welfare institutions, courts of law, administrative authorities or legislative bodies, the best interests of the child shall be a primary consideration. Article 10 (1) In accordance with the obligation of States Parties under article 9, paragraph 1, applications by a child or his or her parents to enter or leave a State Party for the purpose of family reunification shall be dealt with by States Parties in a positive, humane and expeditious manner. States Parties shall further ensure that the submission of such a request shall entail no adverse consequences for the applicants and for the members of their family). 
for the necessity of making decisions on the family reunification of refugees fairly and efficiently ${ }^{63}$.

As regards the right to respect for private and family life from ECHR case law based on Article 8, it seems that in principle it is not possible to derive the right of entry to a given country from the fact that the closest persons who are applying for residence reside there, unless in exceptional circumstances when this is justified ${ }^{64}$. In the refugee context, it is important that the refugee, by definition, cannot return to his country of origin and that persecution (as defined in the Convention) includes large social groups, which usually include all members of a given family. Strasbourg case law requires further analysis as it is relatively scarce in this regard ${ }^{65}$. Therefore, it is not yet possible to talk of a fixed or even developed but rather a developing case law.

\section{Bibliography}

1. Balcerzak M., Odpowiedzialność państwa-strony Europejskiej konwencji ochronie praw człowieka i podstawowych wolności. Studium prawnomiędzynarodowe, TNOiK, Torun 2013.

2. Costello C., The Human Rights of Migrants in European Law, Oxford University Press, Oxford 2016.

3. Garlicki L., Konwencja o ochronie praw człowieka i podstawowych wolności. Tom I. Komentarz do artykułów 1-18, CH Beck, Warsaw 2010.

63 Tanda-Muzinga v. France, No. 2260/10, Judgment of the ECHR of 10.07.2014, para.73; Mugenzi v. France, No. 52701/09, Judgment of the ECHR of 10.1.2014, para. 52; Senigo Longue et al. v. France, No. 19113/09, Judgment of the ECHR of 10.07.2014, para. 67.

${ }_{64}$ Biao v. Denmark, No. 38590/10, Judgment of the Grand Chamber of the ECHR of 24.05. 2016, para. 117; Jeunesse v. the Netherlands, No. 12738/10, Judgment of the Great Chamber of the ECHR of 3.10.2016, paras. 106-108; Tuquabo-Tekle and Others v. the Netherlands, No. 60665/00, ECHR Judgment of 1.12.2005, paras. 42-44; see also N. Mole, C. Meredith, Asylum and the European Convention on Human Rights, Council of Europe Publishing, Strasbourg 2010, pp. 180-189.

65 From a practical point of view, a reference to strictly EU law, including Council Directive 2003/86/EC of 22.09.2003 on the right to family reunification and Directive of the European Parliament and the Council 2011/95/EU of 13.12.2011 on standards for the qualification of third country nationals or stateless persons as beneficiaries of international protection, uniform status for refugees or for persons eligible for subsidiary protection, seem more favourable to refugees and migrants. 
4. Goodwin-Gill G.S., McAdam J., The Refugee in International Law, Oxford University Press, Oxford 2007.

5. Góralczyk W., Sawicki S., Prawo międzynarodowe publiczne, Wolters Kluwer, Warsaw 2015.

6. Harris D., O'Boyle M. (eds.), Harris, O’Boyle \& Warbrick: Law of the European Convention on Human Rights, Oxford University Press, Oxford 2014.

7. Jarmoszka M., Reguły wykładni Karty praw podstawowych Unii Europejskiej [in:] Mik C., Gałka K. (ed.), 'Prawa podstawowe w prawie i praktyce Unii Europejskiej', TNOiK, Torun 2009.

8. Jasiński F., Karta praw podstawowych: struktura, zakres regulacyjny i dotychczasowe znaczenie w praktyce [in:] Barcz J. (ed.), 'Ochrona praw podstawowych w Unii Europejskiej’, C.H. Beck, Warsaw 2008.

9. Mik C., Europejskie prawo wspólnotowe. Zagadnienia teorii i praktyki, C.H. Beck, Warsaw 2000.

10. Mik C., Karta praw podstawowych Unii Europejskiej. Zagadnienia podstawowe [in:] Edit. Podraza A., 'Traktat Nicejski', TN KUL, Lublin 2001.

11. Mik C., Znaczenie postanowień EKPCz dla ochrony praw podstawowych jako ogólnych zasad prawa UE [in:] J. Barcz (ed.), 'Ochrona praw podstawowych w Unii Europejskiej', C.H. Beck, Warszawa 2008.

12. Milanović M., Al-Skeini and Al-Jedda in Strasbourg, 'European Journal of International Law' 2012, vol. 23, no 1.

13. Nowicki M.A., Wokót Konwencji Europejskiej. Komentarz do Europejskiej Konwencji Praw Człowieka, Wolters Kluwer, SIP Lex 2017.

14. Ostropolski T., Zasada jurysdykcji uniwersalnej w prawie międzynarodowym, Instytut Wydawniczy Euro Prawo, Warsaw 2008.

15. Peers S. et al. (ed.), The EU Charter of Fundamental Rights: A Commentary, CH Beck-Hart-Nomos, Oxford 2014.

16. Pugh M., Legal Aspects of the Rainbow Warner Affair, 'The International and Comparative Law Quarterly' 1987, vol. 36, no 3. 